\title{
CONTENTS VOLUME 8 (1990)
}

Editorial

Information management education: alliances and alignments

M. BROADBENT

Systems analysis and design course: a project orientation

B.N. FARAH

Continuing education in library and information science: a survey of needs and attitudes in Israe B.C. PERITZ and T. SHAGAM

Writing a project: a library user education package for engineering students M. SHOOLBRED

General programme for training in agricultural information (Short Communication) M.J. MENOU and T. NIANG

Book Reviews

Book Notices

Software Review

Calendar of Events

Student learning in a fieldwork programme

The transformation of library education in Australia

S.F. BURGESS and S.E. EDWARDS

Macros for the production of simple computer-aided instruction packages (Short Communication)

K.V. TRICKEY

Library training in Denmark: some observations on recent developments (Short Communication)

D. WESTLEY

Archival training in Europe: dilemmas (Short Communication)

A. THURSTON

0167-8329/91/\$03.50 (1) 1991 - Elsevier Science Publishers B.V. 
Meeting Report

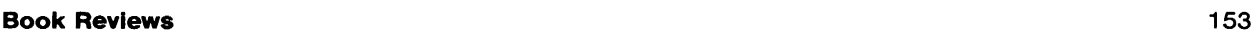

$\begin{array}{ll}\text { Book Notices } & 157\end{array}$

$\begin{array}{ll}\text { News } & 159\end{array}$

Calendar of Events $\quad 167$

Editorial $\quad 171$

Education and training for librarianship and information work: Annual Bibliography, 1989 A.J. CLARK

Information services in crisis and the post-industrial society

Y. COURRIER

Librans prefer Italian food: an alternative approach to introducing database K.V. TRICKEY

The future of library and information science education in Ghana (Short Communication) A.A. ALEMNA

Barriers to the flow of books: a statement by ELP (Short Communication)

News from the Schools

Book Reviews

News

Guest Editorial

Interactive audio classrooms: key principles for effective practice

E.J. BURGE and J.E. SNOW

Providing home computing facilities for students learning at a distance

A. JONES

The use of distance education in United States library and information science: history and current perspectives

D.D. BARRON

Aberystwyth - at a distance

R.J. EDWARDS, D.H.E. ROBERTS and M.F. TUNLEY $\quad 341$

$\begin{array}{lr}\text { Book Reviews } & 349\end{array}$

$\begin{array}{lr}\text { Calendar of Events } & 361\end{array}$

$\begin{array}{lr}\text { Author Index Volume } 8 & 363\end{array}$

$\begin{array}{lr}\text { Contents Volume } 8 & 365\end{array}$ 